\title{
Formula Organik Cair untuk Menambah Masa Tanam Semanggi di Lahan Kering
}

\author{
Liquid Organic Formula to Increase Clover Growing Period in Dry Land \\ Adi Budiwan', Dwiyana Anela Kurniasari ${ }^{2}$, Heri Susanto ${ }^{3}$ \\ ${ }^{1,2,3}$ Program Studi Agribisnis, Fakultas Pertanian, Universitas Wijaya Putra Surabaya
}

\begin{tabular}{l} 
ARTICLE INFO \\
\hline Article history: \\
DOI: \\
10.30595/pspfs.v2i.166 \\
Submitted: \\
July 29, 2021 \\
Accepted: \\
Sept 10, 2021 \\
Published: \\
Nov 10, 2021 \\
\hline
\end{tabular}

\section{Keywords:}

Demonstration Plot, FOC, Vegetable Pesticides

\begin{abstract}
Clover farmers in Semanggi Village, Community Unit 3 of Kendung Sememi, Surabaya, plant clover every year. Clover is a year-round plant. In the long dry season, it is very risky to die. With intensive watering treatment and organic fertilizer, it is expected to grow better and produce very high yields. A demonstration plot of clover land would provide innovation in optimal and eco-friendly clover cultivation. The method of activities in this training included lectures on understanding clover cultivation in dry land and how to provide the right fertilizer for clover. Preparation for Implementation, Preparation of Business Places, Demonstration of clover cultivation in dry land required a plot of land available with complete facilities. The tools needed were provided in the right amount so that the demonstration plot process was not complicated. The physical yield of clover, seen from the leaves, was quite satisfactory because the leaves were wide enough (quality) and would automatically increase the mass volume in terms of weight (quantity).
\end{abstract}

This work is licensed under a Creative Commons Attribution 4.0 International License.

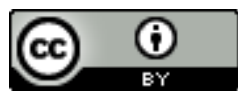

Corresponding Author:

Adi Budiwan

Program Studi Agribisnis, Fakultas Pertanian

Universitas Wijaya Putra Surabaya

Email: adibudiwan@uwp.ac.id

\section{PENDAHULUAN}

Program Pemberdayaan Masyarakat ini bekerjasama dengan satu mitra, yaitu: petani semanggi di Kampung Semanggi RW 3 Kendung Sememi Surabaya, Jawa Timur dengan jarak tempuh sekitar $\pm 3,3 \mathrm{~km}$. Bidang usaha yang dikembangkan oleh mitra tersebut adalah usaha semanggi.

Tanaman semanggi merupakan tanaman sepanjang tahun. Pada musim kemarau yang Panjang sangat berisiko terhadap kematian, apabila dengan perlakuan penyimaran intensif dan penambahan pupuk organik diharapkan mampu untuk tumbuh lebih baik dan menghasilkan hasil yang sangat tinggi.

Loji yang mempunyai sebidang tanah yang terletak di Kendung Sememi Surabaya yang merupakan lahan rawa. Tiap tahunnya ditanami semanggi Petani semanggi adalah petani yang terbentuk berdasarkan kesamaan profesi yaitu sebagai pembudidaya semanggi. Petani semanggi yang meliputi bapak kepala rumah tangga yang berprofesi sebagai petani, istri petani atau anak petani serta masyarakat lain yang tertarik mengembangkan petanian semanggi. Alasan kuat mereka adalah hasil petanian yang berupa semanggi cukup menjajikan dan mempunyai prospek yang cukup bagus. Oleh karena itu kami menciptakan sebuah budidaya semanggi di lahan kering. Biasanya semanggi di budidayakn di rawa yang kondisi airnya tercukupi. Akan tetapi pada saat musim kemarau, petani banyak yang mengeluh banyak tanaman mereka banyak yang mati. 
Permasalahan yang dihadapi oleh mitra usaha adalah tanaman semanggi merupakan tanaman yang tempatnya di rawa-rawa dan membutukan cukup air, saat musim kemarau semanggi tidak tahan terhadap kekeringan, apabila dengan perlakuan penyiraman pupuk organik secara intensif diharapkan mampu tumbuh lebih baik dan menghasilkan hasil yang bagus. Selain mengandung hara yang komplit, pupuk organik bersifat higroskopis, bisa meyimpan air di saat musim kemarau, yang diharapkan menopang pertumbuhan semanggi pada saat musim kemarau.

Kegiatan PPM ini berusaha untuk memecahkan permasalahan yang dihadapi mitra usaha dengan perlakuan penyiraman pupuk organik secara intensif dan perberian pestisida organik secara berkala, sehingga menghasilkan tanaman semanggi yang ramah lingkungan.

\section{METODE PENELITIAN}

Adapun pelaksanaan meliputi survai dan penjajagan sejauh kualitas dan kuantitas, pengumpulan data berkaitan dengan luas lahan, jumlah petani, jumlah panen, kualitas hasil panen, dan metode pelaksanaan yang telah dilakukan, solusi melalui pembuatan pestisida organik dan demplot semanggi lahan kering, manbandingkan hasil dengan menghitung nilai tambah.

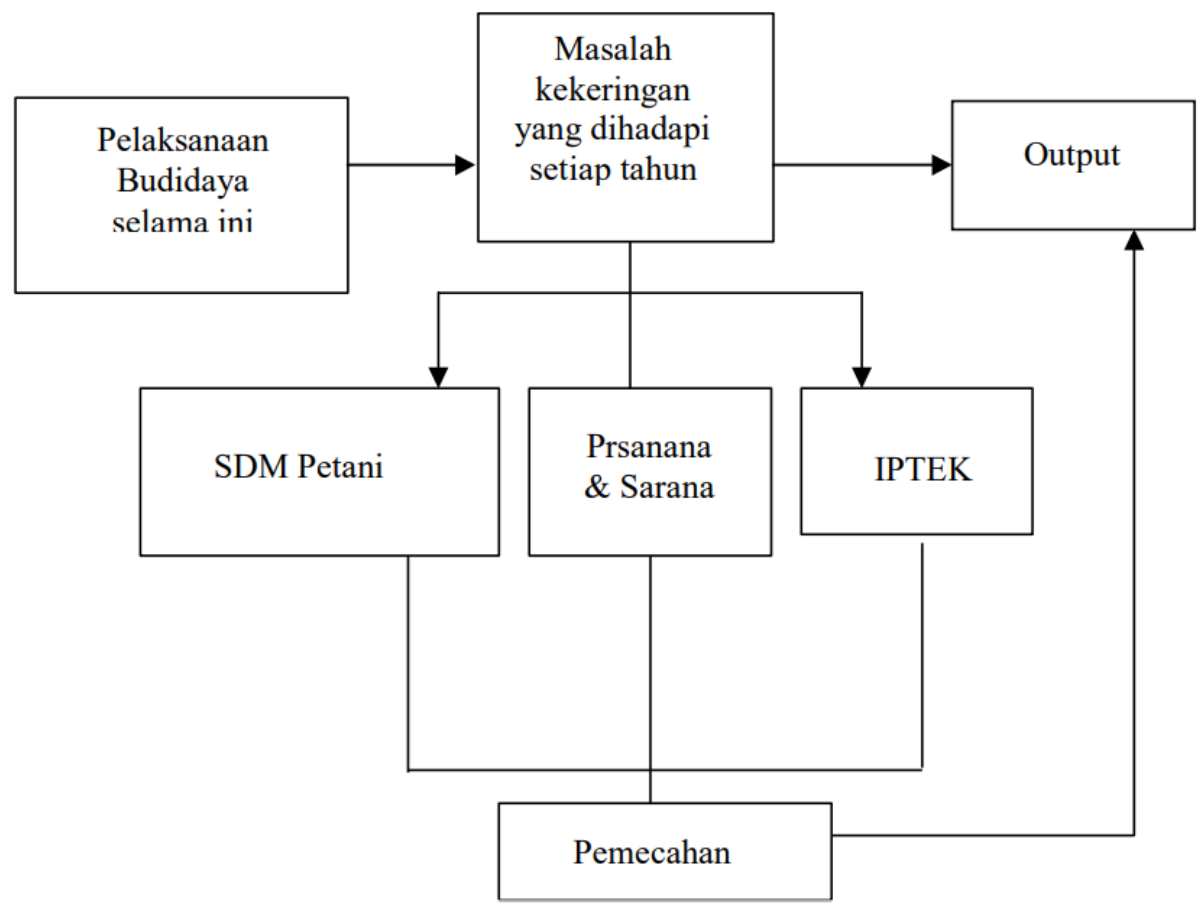

Gambar 1. Kerangka Pemecahan Masalah

\section{HASIL DAN PEMBAHASAN}

Pestisida nabati adalah pestisida yang bahan aktifnya berasal dari tumbuhan atau bagian tumbuhan seperti akar, daun, batang atau buah (Rahardjo, 2010). Bahan-bahan ini diolah menjadi berbagai bentuk, antara lain bahan mentah berbentuk tepung, ekstrak atau resin yang merupakan hasil pengambilan cairan metabolit sekunder dari bagian tumbuhan atau bagian tumbuhan dibakar untuk diambil abunya dan digunakan sebagai pestisida. Beberapa tanaman telah diketahui mengandung bahan- bahan kimia yang dapat membunuh, menarik, atau menolak serangga. Beberapa tumbuhan menghasilkan racun, ada juga yang mengandung senyawasenyawa kompleks yang dapat mengganggu siklus pertumbuhan serangga, sistem pencernaan, atau mengubah perilaku serangga.

\section{Pestisida Nabati Daun Sirsak Dan Tembakau}

- Pestisida nabati daun sirsak dan tembakau efektif untuk mengendalikan hama belalang dan ulat.

- Cara pembuatan: sebanyak 50 lembar daun sirsak dan tembakau satu genggam ditumbuk halus. Bahan-bahan tersebut dimasukkan ke dalam larutan 20 liter air dan 20 gram detergen (sabun solek), diaduk rata, dan direndam selama semalam, kemudian disaring. Tiap 1 liter larutan hasil penyaringan diencerkan dengan 5060 liter air.

- Larutan pengenceran siap digunakan. 
Pupuk merupakan bahan yang ditambahkan ke dalam tanah untuk menyediakan unsur hara yang penting bagi pertumbuhan tanaman. Penggolongan pupuk umumnya didasarkan pada sumber bahan yang digunakan, cara aplikasi, bentuk dan kandungan unsur haranya. (Hadisuwito, 2012)

\section{Formula Organik Cair}

Pupuk organik merupakan hasil atau sisa hasil akhir dan perubahan atau peruraian bagianbagian atau sisa-sisa tanaman dan binatang, misalnya pupuk kandang, pupuk hijau, kompos, bungkil, guano, tepung tulang serta limbah-limbah organik yang lain yang telah dikelola dan dapat memasok unsur hara yang dibutuhkan oleh tanaman.

Pupuk organik mempunyai karakteristik kandungan hara rendah, ketersediaan unsur hara lambat, dan menyediakan hara dalam jumlah terbatas dan hara rendah.Ada beberapa manfaat pupuk yang berkaitan dengan sifat kimia tanah. Manfaat pupuk yang paling banyak dirasakan penggunaannnya adalah: menyediakan unsur hara yang diperlukan bagian tanaman, membantu mencegah kehilangan unsur hara yang cepat hilang seperti nitrogen, fosfor dan kalium., memperbaiki keasaman tanah (Marsono, 2001).

\section{Praktek Budidaya Tanaman Semanggi}

Semanggi akan bertumbuh sangat baik di dalam empang kebun. Cukup masukkan bibit semanggi ke lahan lalu siram Formula Organik Cair ke lahan tersebut. Setelah itu, tidak perlu memberi perhatian, karena Semanggi sanggup mengurus diri sendiri.

Semanggi beradaptasi cepat dengan kedalaman air sedangkan kualitas air dengan penambahan Formula Organik Cair terlihat sangat berpengaruh terhadap petumbuhan. Semanggi dapat di tanam dengan lahan yang tidak berair, tanaman ini akan dengan sendirinya menyesuaikan diri terhadap kondisi tanah yang diperlakukan hingga daun-daunnya mengembang dengan subur.

Penggunaan Formula Organik Cair di siramkan 2 (dua) hari sekali dengan takaran 25 (duapuluh lima) $\mathrm{ml}$ (FOC) dicampurkan dengan 5 (lima) 1 air, kemudian disemprotkan secara merata.

Pengguanaan pestisida nabati di siramkan 1 (satu) minggu sekali dengan takaran 1 (satu) 1 pestisida nabati dilarutkan dengan 50 (limapuluh) 1 air, kemudian diseprotkan secara merata. Tujuan digunakan pestisida nabati untuk pengendalian hama, terutama hama balalang dan ulat. Melihat daerah sekitar masih banyak rawa yang ditumbuhi tumbuhan liar (gulma) sehingga dijadikan sarang bagi haha-hama tersebut.

Setelah perawatan dilakukan dengan baik, maka tinggal melakukan pemanenan semanggi. Pemanenan semanggi dilakukan 2 (dua) minggu sekali dengan cara memotong semanggi sampai hampir batang bawah. Selanjutnya dilakukan perawatan seperti semula dengan pemberian Formula Organik Cair dan pestisida nabati secara tepat.

Hasil panen semanggi secara fisik dilihat dari daunnya cukup memuaskan dalam artian daun cukup lebar (kualitas), dan otomatis akan menambah volume berat dalam bobotnya (kuantitas).

\section{KESIMPULAN}

Dari hasil pembahasan diatas dapat ditarik suatu kesimpulan bahwa:

1. Penanaman semanggi dapat dilakukan di lahan tanpa air dengan perlakuan penyiraan secara intensif, sehingga dapat masa tanam di lahan kering.

2. Dengan penyiraman Formula Organik Cair yang intensif dan penggunaan pestisida nabati yang tepat, terbukti meningkat secara kualitas dan kuantitas.

\section{DAFTAR PUSTAKA}

Firda Kurniawati. 2019. Semanggi Suroboyo Desa Kendung Benowo-Surabaya Sebagai Sumber Belajar Berbasis Etnopedagogi Di Sekolah Dasar. JPGSD. Volume 07 Nomor 03 Tahun 2019, 3061 - 3070.

Hadisuwito, sukamto. 2012. Membuat Pupuk Cair. PT. Agro Media Pustaka, Jakarta.

Hery Widijanto, Suntoro. 2019. Pembuatan Demplot Budidaya Tanaman Jagung Dalam Menambah Masa Tanam Di Lahan Kering Dengan Memanfaatkan Pupuk organik. PRIMA: Journal of Community Empowering and Services. 28-32 e- ISSN: 2579-5074.

Marsono, P. S. 2001. Pupuk Akar, Jenis dan Aplikasi. Penebar Swadaya, Jakarta.

Soenandar, M., M. N. Aeni, dan A. Rahardjo. 2010. Petunjuk Praktik Membuat Pestisida Organik. Agromedia Pustaka, Jakarta. 